\title{
APLIKASI TEPUNG TESTIS SAPI YANG MENGANDUNG rGH DALAM PAKAN BUATAN TERHADAP RASIO JENIS KELAMIN, PERTUMBUHAN DAN KELULUSHIDUPAN IKAN NILA (Oreochromis niloticus)
}

\author{
Rachmat Nurul Huda, Titik Susilowati dan Tristiana Yuniarti \\ Departemen Akuakultur, Fakultas Perikanan dan Ilmu KelautanUniversitas Diponegoro
}

\begin{abstract}
ABSTRAK
Budidaya ikan nila (Oreochromis niloticus) terus dikembangkan hingga saat ini. Berbagai teknologi dalam bidang perikanan telah diterapkan, salah satunya yaitu sex reversal dalam hal ini jantanisasi. Ikan nila jantan lebih cepat pertumbuhannya dari pada ikan nila betina sehingga dapat meningkatkan hasil produksi. Tujuan penelitian ini yaitu untuk mengetahui pengaruh pemberian tepung testis sapi dan dosis terbaik tepung testis sapi dalam pakan yang mengandung $\mathrm{rGH}$ terhadap rasio jenis kelamin, pertumbuhan dan kelulushidupan ikan nila. Bahan uji yang digunakan adalah larva ikan nila dengan stadia larva yang berumur 7 hari setelah lepas kuning telur dan memiliki bobot rata-rata 0,07 gram/ekor. Penelitian ini menggunakan metode eksperimental dengan Rancangan Acak Lengkap 4 perlakuan dan 3 kali ulangan. Perlakuan dalam penelitian ini yaitu dengan menambahkan tepung testis sapi dengan dosis pada perlakuan A (0\%/kg pakan), perlakuan B (3\%/kg pakan), perlakuan C $(6 \% / \mathrm{kg}$ pakan) dan, perlakuan D (9\%/kg pakan). Pakan pada setiap perlakuan dalam penelitian ini telah ditambahkan rGH dengan dosis $2 \mathrm{mg} / \mathrm{kg}$ pakan. Data yang diamati meliputi rasio jenis kelamin, laju pertumbuhan spesifik (SGR), dan tingkat kelulushidupan (SR) ikan nila. Hasil penelitian menunjukan bahwa perlakuan C (6\% tepung testis sapi/kg pakan) memberikan hasil terbaik dimana nilai rasio jenis kelamin jantan sebesar 74,44 $\pm 5,09 \%$ dan laju pertumbuhan spesifik sebesar $9,48 \pm 0,10 \%$ bobot/hari. Kesimpulan yang diperoleh dalam penelitian ini yaitu adanya pengaruh nyata terhadap rasio jenis kelamin dan tingkat pertumbuhan spesifik, namun tidak berpengaruh nyata terhadap tingkat kelulushidupan ikan nila dengan pemberian dosis tepung testis sapi terbaik adalah $6 \%$ tepung testis sapi/kg pakan.
\end{abstract}

Kata kunci: Sex reversal; Tepung testis sapi; Pertumbuhan, rGH; Nila

\begin{abstract}
Tilapia fish (Oreochromis niloticus) cultivation still continue to be developed until nowdays. Many fisheries technology had been applied, and one of them is sex reversal which is masculinization. Male tilapia fish grows faster than the female one, so this can boost the produce of the fish. This research aims to know the effect of cow testicle flour addition and determine the best dosage on the fish feed which contains rGH towards the male-sex ratio, growth, and survival rate of tilapia fish. The material which used in this research was tilapia fish $(O$. niloticus $)$ which under the larvae phase 7 days post the separated egg yolk which have average weight of 0,07 grams/each. This research used experimental methods with Completely Randomized Design of 4 treatments and 3 times of repetitions. The treatments in this research was addition of different dosage of bull testicle which treatment $\mathrm{A}$ $(0 \% / \mathrm{kg}$ fish feed), treatment B (3\%/kg fish feed), treatment C (6\%/kg fish feed) and, treatment D (9\%/kg fish feed). The fish feed in every treatment had been added with $2 \mathrm{mg} \mathrm{rGH} / \mathrm{kg}$ fish feed. Data observation during this research were male-sex ratio, specific growth rate (SGR), and survival rate (SR) of tilapia fish. Results of the research showed that treatment $\mathrm{C}(6 \% / \mathrm{kg}$ fish feed $)$ gave the best result as male-sex ratio by $74,44 \pm 5,09 \%$ and specific growth rate by $9,48 \pm 0,10 \%$ weight/day. Conclusion obtained from this research was: there was different result towards the male-sex ratio and specific growth rate, but there was no difference between the treatments towards the survival rate, the best bull testicle flour dosage was $6 \% / \mathrm{kg}$ fish feed.
\end{abstract}

Keywords: Sex reversal, Bull testicle flour, Growth, rGH, Tilapia 


\section{PENDAHULUAN}

Secara biologis, laju pertumbuhan ikan nila jantan lebih cepat dibandingkan dengan nila betina (sex dimorphism). Data-data empiris menunjukkan bahwa penggunaan populasi tunggal kelamin (monosex) jantan pada budidaya ikan nila akan memberikan produksi lebih baik dibandingkan populasi campuran (mixed-sex) (Ariyanto et al., 2010). Masalah umum yang dihadapi dalam budidaya ikan nila adalah kemampuan reproduksi ikan yang tinggi sehingga sukar diatur dan sering terjadi inbreeding. Hal tersebut menyebabkan tingkat pertumbuhan ikan menjadi lambat sehingga diperlukan waktu yang lama untuk mencapai ukuran konsumsi, bahkan pertumbuhannya sering terhenti (Mantau et al., 2001). Untuk mengatasi permasalahan tersebut perlu dikembangkan alternatif budidaya dengan pemeliharaan ikan secara tunggal kelamin, yaitu hanya memelihara benih ikan nila jantan, karena pertumbuhannya lebih cepat dan ukurannya lebih besar dibandingkan nila betina.

Produksi ikan nila jantan (jantanisasi) sangat perlu guna memaksimalkan tingkat pertumbuhan ikan nila. Metode yang dipakai dalam jantanisasi pada penelitian ini yaitu dengan metodeoral dimana perlakuan uji dilakukan dengan memberikan tepung testis sapi dalam pakan dan rGH. Tepung testis sapi memiliki kandungan hormon testosteron alami dimana kandungan hormon ini diperlukan untuk merangsang proses differensiasi kelamin jantan. Penambahan rGH dalam pakan dapat memacu pertumbuhan ikan. Acosta et al., (2007), menjelaskan bahwa penggunaan protein rGH ikan dalam meningkatkan produktivitas atau pertumbuhan ikan budidaya.

Testis sebagai organ kelamin primer mempunyai dua fungsi yaitu menghasilkan spermatozoa atau sel-sel kelamin jantan, dan mensekresikan hormon kelamin jantan (testosteron). Spermatozoa dihasilkan di dalam tubuli seminiferi sedangkan hormon androgen (testosteron) diproduksi oleh selsel interstitial dari Leydig (Taylor dan Thomas, 2004). Menurut Lindner (1961), kandungan hormon testosteron dalam testis sapi berkisar antara 14-231 $\mu \mathrm{g} /$ testis. Menurut Hay et al (1961) konsentrasi hormon dalam testis sapi berkisar 0-25 mg/100 g. Menurut Hafez (1980), pada sapi kandungan hormon testosteron dalam cairan testis (testicular fluid) sebanyak 2,3 $\mu \mathrm{g} / 100$ ml. Menurut Iskandariah (1996), testis sapi segar mengandung hormon testosteron alami berkisar 2300-27700 pg/g testis dan protein 63,49\%. Menurut penelitian Muslim (2012), kandungan hormon metiltestosteron yang 
ada pada tepung testis sapi yaitu sebesar $10.01 \mu / g$. dengan kandungan protein sebesar $76.26 \%$, lemak $13.40 \%$, kadar abu 7.41\%, serat kasar $0.02 \%$ dan BETN $2.91 \%$.

Penelitian ini memodifikasi penilitian Muslim (2012), dimana dosis penggunaan tepung testis sapi sebesar $0 \% / \mathrm{kg}$ pakan, $3 \% / \mathrm{kg}$ pakan, $6 \% / \mathrm{kg}$ pakan dan $9 \% / \mathrm{kg}$ pakan yang diaplikasikan pada ikan nila. Penentuan dosis rGH dalam pakan yang digunakan mengacu pada hasil terbaik penelitian Sibarani (2015), yaitu $2 \mathrm{ml} / \mathrm{kg}$ pakan yang diaplikasikan pada ikan nila.

Tujuan dari penelitian ini adalah mengetahui pengaruh dosis pemberian tepung testis sapi dalam pakan yang mengandung $\mathrm{rGH}$ terhadap rasio jenis kelamin, pertumbuan dan kelulushidupan dan mengetahui dosis tepung testis sapi terbaik dalam pakan yang mengandung rGH pada ikan nila. Penelitian ini dilaksanakan pada bulan November 2016 sampai Januari 2017. Pengamatan terhadap pertumbuhan ikan nila larasati dilakukan selama 42 hari yang bertempat di SATKER PBIAT Janti, Klaten.

\section{METODE PENELITIAN}

Bahan uji yang digunakan adalah larva ikan nila dengan bobot rata-rata 0,07 gram/ekor dengan kepadatan 80 ekor per wadah pemeliharaan. Jumlah wadah total yang digunakan yaitu 12 wadah pemeliharaan untuk 4 perlakuan dan 3 kali ulangan. Wadah yang digunakan pada penelitian berupa ember dengan volume 40 liter.Pakan uji yang digunakan dalam penelitian adalah pakan buatan berbentuk serbuk dengan kandungan protein $30 \%$. Penentuanperlakuan berdasarkan perbedaan pemberian dosis tepung testis sapi di setiap perlakuan yaitu perlakuan A (0\%/kg pakan), perlakuan B (3\%/kg pakan), perlakuan C (6\%/kg pakan) dan, perlakuan D $(9 \% / \mathrm{kg}$ pakan). Pakan pada setiap perlakuan telah ditambahkan $\mathrm{rGH}$ dengan dosis $2 \mathrm{mg} / \mathrm{kg}$ pakan. Pengecekan kualitas air dilakukan setiap 7 hari sekali yaitu $\mathrm{DO}$ dan $\mathrm{pH}$, sedangkan untuk suhu dilakukan setiap hari.

Persiapan pakan uji dilakukan dengan penentuan dosis rGH yang digunakan per kilogram pakan. Setelah rGH sudah ditentukan dosisnya lalu rGH dicampurkan dengan larutan PBS sebanyak $100 \mathrm{ml}$. Pencampuran rGH dan PBS dilakukan dengan menggojog dalam botol sprayer dan kemudian menyemprotkan rGH yang telah dilarutkan tadi secara merata ke dalam pakan sembari diaduk agar homogen. Setelah pakan uji siap lalu dilakukan penepungan testis sapi. Testis sapi yang masih segar kemudian dipotong kecil-kecil 
dan dilakukan penjemuran selama 1 hari penuh guna mengurangi kadar air yang ada pada testis sapi. Setelah kering kemudian dilakukan penepungan dengan alat penepung. Tepung testis sapi yang didapat kemudian dicampurkan ke pakan yang telah mengandung rGH kemudian pakan dibungkus dengan plastik rapat dan disimpan pada tempat yang terlindung dari sinar matahari.

Persiapan bahan uji dilakukan dengan penyeragaman ikan yang memiliki umur 7 hari setelah lepas kuning telur menggunakan ember grading. Setelah didapat ikan uji yang seragam lalu ikan uji dipindahkan ke dalam masing-masing ember pemeliharaan. Setelah ikan uji berada pada masing-masing ember perlakuan lalu ikan uji diberi pakan sesuai perlakuan uji. Pemberian pakan uji dilakukan dengan metode ad satiation pada pagi, siang dan sore hari selama 42 hari penelitian berlangsung.Pemeliharaan kualitas air dilakukan dengan cara menyipon wadah pemeliharaan setiap dua sampai tiga hari sekali.

Metode yang digunakan dalam penelitian ini adalah metode eksperimen. Menurut Setyanto (2005), metode eksperimen bertujuan untuk meneliti kemungkinan sebab akibat dengan mengenakan satu atau lebih kondisi perlakuan pada satu atau lebih kelompok eksperimen dan membandingkan hasilnya dengan satu atau lebih kelompok kontrol yang tidak diberi perlakuan.

Variabel pengamatan data yang dikumpulkan meliputi rasio jenis kelamin, laju pertumbuhan spesifik (SGR), tingkat kelulushidupan (SR), dan kualitas air.

\section{Rasio Jenis Kelamin}

Rasio Jenis kelamin jantan ditentukan dengan menggunakan rumus sebagai berikut:

$$
\% \text { jantan }: \frac{\sum \text { jantan }}{\sum \text { ikan yang diamati }} \times 100 \%
$$

\section{Laju Pertumbuhan Spesifik (SGR)}

Laju pertumbuhan spesifik dihitung dengan menggunakan rumus dari Zooneveld et al. (1991) yaitu:

$$
\mathrm{SGR}=\frac{\operatorname{Ln} W_{t}-\operatorname{Ln} W_{0}}{\mathrm{t}} X 100 \%
$$

Keterangan :

SGR $=$ Laju pertumbuhan spesifik $(\%$ bobot/hari)

$\mathrm{W}_{0}=$ Bobot hewan uji pada awal penelitian (gram)

$\mathrm{W}_{\mathrm{t}}=$ Bobot hewan uji pada akhir penelitian (gram)

$\mathrm{t}=$ Waktu penelitian (hari) 


\section{Kelulushidupan (SR)}

Kelulushidupan dapat dihitung menggunakan rumus Effendie (1979), yaitu:

Survival Rate $(\mathrm{SR})=\frac{\text { jumlah ikan akhir }}{\text { jumlah ikan awal }} \times 100 \%$

\section{Kualitas Air}

Parameter kualitas air yang diamati meliputi suhu yang dilakukan pengukuran setiap hari, oksigen terlarut (DO) dan $\mathrm{pH}$ yang dilakukan pengukuran setiap satu minggu sekali.

\section{Analisa Data}

Data yang didapatkan kemudian di analisa menggunakan analisa ragam (ANOVA). Sebelum dilakukan analisa ragam, data terlebih dahulu dilakukan uji normalitas, uji homogenitas dan uji adivitas untuk mengetahui bahwa data bersifat normal, homogen dan aditif. Setelah dilakukan analisa ragam, apabila diperoleh hasil berpengaruh nyata $(\mathrm{P}<0,05)$ maka kemudian dilakukan uji wilayah ganda Duncan untuk dapat mengetahui perbedaan nilai tengah antar perlakuan. Data kualitas air dianalisis secara deskriptif.

\section{HASIL DAN PEMBAHASAN}

Hasil penelitian laju pertumbuhan spesifik, presentase kelamin jantan dan kelulushidupan dapat dilihat pada tabel 1.

Tabe 1. Hasil pengukuran Laju Pertumbuhan Spesifik, Rasio Jenis Kelamin dan SR Ikan nila selama penelitian.

\begin{tabular}{|c|c|c|c|c|}
\hline \multirow{2}{*}{$\begin{array}{c}\text { Data yang } \\
\text { Diamati }\end{array}$} & \multicolumn{4}{|c|}{ Perlakuan } \\
\hline & A & B & $\mathrm{C}$ & D \\
\hline $\begin{array}{c}\text { Rasio } \\
\text { Jenis } \\
\text { Kelamin } \\
(\% \text { jantan }) \\
\end{array}$ & $\begin{array}{c}62.22 \pm \\
5.09^{\mathrm{b}}\end{array}$ & $\begin{array}{c}65.56 \pm \\
1.92^{\mathrm{b}}\end{array}$ & $\begin{array}{c}74.44 \pm \\
5.09^{\mathrm{a}}\end{array}$ & $\begin{array}{c}70.00 \pm 3 \\
.33^{\mathrm{ab}}\end{array}$ \\
\hline $\begin{array}{c}\text { Laju } \\
\text { Pertumbu } \\
\text { han } \\
\text { Spesifik } \\
(\% \\
\text { bobot/hari } \\
\text { ) }\end{array}$ & $\begin{array}{c}8.84 \pm 0 . \\
12^{\text {bc }}\end{array}$ & $\begin{array}{c}9.25 \pm 0 . \\
03^{\mathrm{b}}\end{array}$ & $\begin{array}{c}9.48 \pm 0 . \\
10^{\mathrm{a}}\end{array}$ & $\begin{array}{c}9.27 \pm 0 . \\
04^{\mathrm{b}}\end{array}$ \\
\hline $\begin{array}{c}\text { Tingkat } \\
\text { Kelulushi } \\
\text { dupan }(\%)\end{array}$ & $\begin{array}{c}94.58 \pm \\
0.72^{\mathrm{a}}\end{array}$ & $\begin{array}{c}94.17 \pm \\
1.44^{\mathrm{a}}\end{array}$ & $\begin{array}{c}93.33 \pm \\
0.72^{\mathrm{a}}\end{array}$ & $\begin{array}{c}92.50 \pm 1 \\
.25^{\mathrm{a}}\end{array}$ \\
\hline
\end{tabular}

Keterangan :

Perlakuan A : Dosis tepung testis sapi $0 \% / \mathrm{kg}$ pakan

Perlakuan B : Dosis tepung testis sapi $3 \% / \mathrm{kg}$ pakan

Perlakuan C : Dosis tepung testis sapi $6 \% / \mathrm{kg}$ pakan

Perlakuan D : Dosis tepung testis sapi 9\%/kg pakan

Pakan telah ditambah rGH dengan dosis $2 \mathrm{mg} / \mathrm{kg}$ pakan pada setiap perlakuan. Nilai dengan Supercript yang sama pada kolom menunjukkan tidakadanya perbedaan yang nyata. 
Hasil pengukuran kualitas air selama penelitiandapat dilihat pada Tabel 2. Selain pengukuran kualitas air, dilakukan juga monitoring kondisi lingkungan setiap hari.

Tabel 2. Hasil Parameter Kualitas Air pada Ikan nila larasati (O. niloticus) selama Penelitian.

\begin{tabular}{clcc}
\hline No & Parameter & Kisaran & Kelayakan \\
\hline 1 & Suhu $\left({ }^{\circ} \mathrm{C}\right)$ & $26-30$ & $25-32^{*}$ \\
2 & pH & $7-8$ & $6,5-9,0^{*}$ \\
3 & DO $(\mathrm{mg} / \mathrm{l})$ & $3.13-5.25$ & $3-5^{*}$ \\
\hline
\end{tabular}

Keterangan: *SNI (2009)

\section{Laju Pertumbuhan Spesifik}

Berdasatkan hasil penelitian yang telah dilakukan, didapatkan hasil nilai pertunbuhan spesifiik yang kemudian dilakukan analisis ragam dan dapat disimpulkan bahwa pemberian tepung testis sapi dalam pakan dan rGH berpengaruh sangat nyata $(\mathrm{P}<0.01)$ terhadap laju pertumbuhan spesifik ikan nila (Oreochromis niloticus). Nilai rata-rata laju pertumbuhan spesifik pada masing-masing perlakuan dari yang tertinggi hingga terendah adalah perlakuan $\mathrm{C}$ sebesar $9,48 \pm 0,10 \%$ bobot/hari, perlakuan D sebesar 9,27 $\pm 0,04 \%$ bobot/hari, perlakuan B sebesar $9,25 \pm 0,03 \%$ bobot/hari dan, perlakuan $\mathrm{A}$ sebesar $8,84 \pm 0,12 \%$ bobot/hari.

Hasil penelitian ini sejalan dengan hasil penelitian yang dilakukan oleh Muslim (2010), dimana pemberian dosis tepung testis sapi sebesar $9 \%$ dalam pakan menghasilkan nilai laju pertumbuhan paling tinggi. Data pertumbuhan ikan uji cenderung meningkat dengan semakin tingginya dosis tepung testis sapi yang diberikan. Perlakuan dosis $9 \%$ pertambahan bobot ikan uji ratarata sebesar $8,3 \pm 0,1$ gram, dosis $6 \%$ sebesar $7,52 \pm 0,02$ gram dan dosis $3 \%$ sebesar 7,26 $\pm 0,01$ gram. Dalam penelitian yang telah dilakukan tidak ada perbedaan nyata dengan uji Duncan antara perlakuan C yang menghasilkan nilai SGR 9,48 $\pm 0,10 \%$ bobot/hari dengan perlakuan D yang menghasilkan nilai SGR sebesar $9,27 \pm 0,04 \%$ bobot/hari, namun berbeda nyata dengan kontrol (perlakuan A) yang menghasilkan nilai SGR sebesar $8,84 \pm 0,12 \% \quad$ bobot/hari, sedangkan perlakuan B menghasilkan nilai laju pertumbuhan spesifik sebesar 9,25 $\pm 0,03 \%$ bobot/hari.

Laju pertumbuhan berhubungan dengan pertambahan bobot tubuh yang dihasilkan dari pemanfaatan protein dalam pakan. Pakan diberi perlakuan yaitu dengan penambahan tepung testis sapi yang berarti kandungan protein dalam tepung testis sapi terkonsumsi oleh ikan yang secara langsung akan mempengaruhi proses pertumbuhan. Menurut Phelps dan Popma (2000), terkait dengan pertumbuhan, hormon androgen 
mempunyai dua aktifitas fisiologi yaitu androgenic activity dan anabolic activity. Pertumbuhan ikan terkait dengan anabolic activity yaitu merangsang biosintesis protein.Peran $\mathrm{rGH}$ yang terkandung dalam pakan dapat meningkatkan pertumbuhan, pemberian $\mathrm{rGH}$ juga dapat meningkatkan kelulushidupan ikan melalui sistem peningkatan kekebalan tubuh terhadap penyakit dan stress (McCormick, 2001).

Telah diketahui bahwa ikan dengan jenis kelamin jantan lebih cepat pertumbuhannya dibandingkan dengan ikan berjenis kelamin betina. Penambahan $\mathrm{rGH}$ dalam pakan juga dapat mempengaruhi pertumbuhan ikan yang mana telah diaplikasikan pada beberapa penelitian sebelumnya tentang rGH yang diaplikasikan pada ikan nila. Menurut Dunham (2004), pertumbuhan ikan nila betina lebih lambat karena kematangan gonad ikan nila betina lebih cepat sehingga energi untuk pertumbuhan berkurang karena digunakan untuk perkembangan telur.

\section{Rasio Jenis Kelamin}

Hasil analisis ragam mengenai nilai rasio jenis kelamin menunjukkan bahwa penambahan tepung testis sapi dalam pakan dan rGH memberikan pengaruh nyata $(\mathrm{P}<0,05)$.Berdasarkan nilai rasio jenis kelamin ikan nila (Oreochromis niloticus) pada masing-masing perlakuan dari yang tertinggi dan terendah adalah perlakuan $\mathrm{C}$ sebesar 74,44 $\pm 5,09 \%$ jantan, perlakuan D sebesar 70,00 $\pm 3,33 \%$ jantan, perlakuan B sebesar $65,56 \pm 1,92 \%$ jantan dan, perlakuan A sebesar 62,22 $\pm 5,09 \%$ jantan.

Tepung testis sapi memiliki kandungan hormon testosteron alami dimana kandungan hormon ini diperlukan untuk merangsang proses differensiasi kelamin jantan. Salah satu cara untuk menghasilkan populasi ikan nila kelamin jantan adalah menggunakan hormon untuk merangsang perubahan kelamin. Hormon yang biasa digunakan adalah hormon methyltestosteron (MT) dicampurkan ke pakan (Phellps and Popma 2000). Penelitian yang dilakukan oleh Muslim (2010), memberikan hasil yang lebih tinggi dari pada penelitian ini yaitu sebesar $83,33 \%$, hal ini dapat dipengaruhi oleh beberapa faktor, diantaranyaadalah: ukuran dan umur, lama perlakuan, lingkungan (Phelps dan Popma, 2000), spesies ikan, genetic, tipe hormon, dosis hormon, waktu perlakuan (Dunham, 2004).

Menurut Muslim (2010), dalam penelitian yang telah dilakukan memberikan hasil rasio jenis kelamin terbaik yaitu sebesar 83,33 $\pm 5,3 \%$ ikan nila (Oreochromis niloticus) jantan pada perlakuan pemberian 
dosistepung testis sapi $6 \%$ dan $9 \%$. Pemberian dosis yang berbeda ini tidak memberikan pengaruh yang nyata antar perlakuan namun berpengaruh sangat nyata terhadap perlakuan kontrol. Terkait dengan hal tersebut, hasil terbaik dari penelitian ini yaitu terdapat pada perlakuan $\mathrm{C}$ dimana penambahan tepung testis sapi dengan dosis 9\%/kg pakan dalam pakan yang mengandung $\mathrm{rGH}$ memberikan hasil jenis

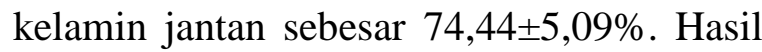
perlakuan $\mathrm{C}$ setelah diuji antar perlakan tidak memberikan perbedaan yang nyata terhadap perlakuan D yaitu sebesar $70,00 \pm 333 \%$ jantan, namun berbeda nyata dengan kontrol (perlakuan A) yaitu sebesar $62,22 \pm 5,09 \%$ jantan.

Beberapa pendapat mengenai lama masa diferensiasi gonad pada ikan nila yang antara lain dijelaskan oleh Kwon et al., (2000), bahwa masa diferensiasi gonad pada ikan nila terjadi hingga 30 hari setelah penetasan, namun periode paling sensitif untuk pengarahan jenis kelamin pada ikan nila adalah pada 7-14 hari setelah menetas.

\section{Tingkat Kelulushidupan}

Hasil analisis ragam menunjukkan bahwa pemberian tepung testis sapi dalam pakan dan rGH tidak berpengaruh nyata (P>0,05) terhadap tingkat kelulushidupan ikan nila (Oreochromis niloticus). Nilai ratarata tingkat kelulushidupan pada masingmasing perlakuan dari yang tertinggi hingga terendah adalah perlakuan A sebesar 94,58\%, perlakuan B sebesar 94,17\%, perlakuan C sebesar 93,33\%, dan perlakuan D sebesar $92,50 \%$.

Menurut Zooneveld et al., (1988), kelulushidupan dapat dipengaruhi oleh faktor biotik dan abiotik. Faktor biotik terdiri dari umur dan kemampuan ikan dalam menyesuaikan diri dengan lingkungan, sedangkan faktor abiotik antara lain ketersediaan makanan dan kualitas air media hidup. Kelulushidupan dalam penelitian ini salah satunya dipengaruhi oleh penggunaan hormon alami dalam setiap perlakuan. Secara umum, perlakuan menggunakan steroid sintetik menghasilkan mortalitas lebih tinggi (Pandian, 1999). Beberapa penelitian maskulinisasi ikan nila menggunakan hormon dan bahan kimia sintetik menghasilkan SR lebih rendah dibandingkan dengan penelitian ini: Shalaby et al,(2007), menggunakan 17 $\alpha$-MT secara immersion/perendaman, SR sebesar 88,2690,98\%; Fitzpatrick et al., (2008), menggunakan 17 $\alpha-\mathrm{MT}$ dan MDHT secara immersion, SR sebesar 42-88\%. 


\section{Kualitas Air}

Hasil nilai kualitas air selama penelitian yaitu suhu berkisar antara 26$30^{\circ} \mathrm{C}, \mathrm{pH} 7-8, \mathrm{DO}$ berkisar antara 3,13-5,25. Hasil tersebut sesuai dengan SNI (2009). Suhu merupakan salah satu faktor yang sangat penting dalam mengatur proses kehidupan dan penyebaran organisme. Metabolisme yang optimum bagi sebagian besar makhluk hiudp membutuhkan kisaran suhu yang relatif sempit (Simanjuntak, 2009). Menurut Reksono (2012) Suhu dan $\mathrm{pH}$ merupakan faktor pembatas yang mempengaruhi dan menentukan kecepatan reaksi metabolisme dalam konsumsi pakan. Jika nilai $\mathrm{pH}$ air rendah dapat menyebabkan terjadinya penggumpalan lendir pada insang dan ikan akan mati lemas sehingga energi untuk mempertahankan tubuh daripada untuk pertumbuhan. Menurut Brett (1979), apabila kandungan oksigen dalam air budidaya ikan kurang dari 3 ppm dan suhu berkisar $20-23^{\circ} \mathrm{C}$ dapat menyebabkan laju pertumbuhan, efisiensi pakan dan jumlah pakan yang diberikan menurun. Boyd (1979) menyatakan bahwa jika oksigen terlarut kurang dari $1 \mathrm{mg} / \mathrm{l}$ dalam waktu yang lama akan menyebabkan kematian.

\section{KESIMPULAN DAN SARAN}

\section{Kesimpulan}

Kesimpulan yang dapat diambil dari hasil penelitian ini adalah sebagai berikut:

1. Pemberian dosis tepung testis sapi dalam pakan yang mengandung $\mathrm{rGH}$ berpengaruh nyata terhadap rasio jenis kelamin dan laju pertumbuhan spesifik, namun tidak berpengaruh nyata terhadap tingkat kelulushidupan ikan nila (Oreochromis niloticus).

2. Pemberian dosis tepung testis sapi terbaik yaitu sebesar $6 \% / \mathrm{kg}$ pakan yang mengandung rGH menghasilkan nilai rata-rata rasio jenis kelamin jantan sebesar $74,44 \pm 5,09 \%$, nilai rata-rata SGR sebesar $9,48 \pm 0,10 \%$ bobot/hari.

\section{Saran}

Saran yang dapat diberikan pada penelitian ini adalah sebagai berikut:

1. Pemberian dosis tepung testis sapi sebesar $6 \% / \mathrm{kg}$ pakan merupakan dosis terbaik untuk menghasilkan ikan Nila berkelamin jantan.

2. Disarankan melakukan penelitian lebihlanjut mengenai pemberian dosis tepung testis sapi yang berbeda dalam pakan dan rGH terhadap spesies ikan yang berbeda. 


\section{UCAPAN TERIMA KASIH}

Terima kasih penulis ucapkan kepada SATKER PBIAT Janti yang telah membantu dalam penelitian ini dan semua pihak yang telah membantu mulai dari persiapan penelitian, terlaksananya penelitian sampai terselesaikannya penelitian ini.

\section{DAFTAR PUSTAKA}

Acosta, J.R., Morales, A., M., Alonso, P.M., 2007. Pichia Pastoris Expressing Recombinant Tilapia Growth Hormone Accelerates The Growth of Tilapia. Biocthenol. 29: 16711676.

Ariyanto, D.K., Sumantadinata, dan A.O. Sudrajat. 2010. Diferensiasi Kelamin Tiga Genotip Ikan Nila yang Diberi Bahan Aromatase Inhibitor. Jurnal Ris Akuakultur. 5(2): 166.

Boyd, C.E. dan F. Lichtkopler. 1979. Water Quality Management in Pond Fish Culture. International Center for Aquacultur, Agricultural Station. Alabama: Auburn University Djajasewaka (1985). Pp. 85-109

Brett, J.R., 1979. Environmental Factors and Growth. Fish Physiology, vol. 8. Academic Press, London, pp. 599-675.

Dunham, R.A. 2004. Aquaculture and Fisheries Biotechnology : Genetic
Approaches. CABI Publ. Cambridge, USA. 357 Pp.

Effendie, M.I. 1979. Metode Biologi Perikanan. Yayasan Dewi Sri. Bogor. Hlm. 112.

Fitzpatrick MS, CB Schreck and WL Gale. 2008. Masculinization of Tilapia Through Immersion in $17 \alpha$ Methyltestosteron or $\quad 17 \alpha-$ Methyldihydrotestosteron. Oregon Cooperative Fishery Research Unit. Oregon State University. Corvallis. USA. 55pp.

Hafez, E.S.E. 1980. Reproduction in Farm Animals. 4th edition. LEA\&FEBIGER.Philadelphia.

Hay, M.F; H.R. Lindner dan T. Mann. 1961. Morphology of Bull Testes and Seminal Vesicles in Relation to Testicular Androgens. Proceedings of the Royal Society of London. Series B, Biological Sciences: 154:433-448.

Iskandariah. 1996. Pemanfaatan Testis Sapi Dalam Teknik Pengalihan Jenis Kelamin (Sex Reversal) Ikan Nila Merah (Oreochromis sp). Skripsi. Universitas Djuanda. Bogor.

Kwon YJ, Haghpanah V, Kongson-Hurtado ML, Mc Andrew JB, and Penman JD. 2000. Masculinization of Genetic Female Nile Tilapia (Oreochromis niloticus) By Dietry Administration of an Aromatase Inhibitor DuringSexual Differentiation. The Journal of Experimental Zoology 287 : 4653.

Lindner, H.R. 1961. Androgenand Related Compounds in The Spermatic Vein Blood of Domestic Animals. Journal of Endocrinology 23 : 139-159 
Mantau, Z. 2005. Produksi Benih Ikan Nila Jantan dengan Rangsangan Hormon Metil Testosteron dalam Tepung Pelet. Jurnal Litbang Pertanian. 24 (2):80-82.

Mc Cormick, S.D. 2001. Endocrine Control Of Osmoregulation In Teleost Fish . Am. 2001. 41: 781-794.

Muslim. 2010. Maskulinisasi Ikan Nila (Oreochromis niloticus) dengan Pemberian Tepung Testis Sapi. Tesis. Fakultas Perikanan dan Ilmu Kelautan, Institut Pertanian Bogor, Bogor. Hlm. 55.

Pandian TJ. 1999. Sex Determination and Differentiation in Teleosts. Science Publisher, Inc. USA. $55 \mathrm{pp}$.

Phelps RP dan Thomas JP. 2000. Sex Reversal of Tilapia. Page 34-59 in B.A. Costa-Pierce and J.E. Rakocy, eds. Tilapia Aquaculture in the Americas, Vol 2. The Word Aquaculture Society, Baton Rounge, Louisiana, United States. $55 \mathrm{pp}$.

Reksono, B., H. Hamdani dan MS. Yuniarti. 2012. Pengaruh Padat Penebaran Gracillaria sp. terhadap Pertumbuhan dan Kelangsungan Hidup Ikan Bandeng (Chanos chanos) pada Budidaya Sistem Polikultur. Jurnal Perikanan dan Kelautan. 3(3): $41-49$.

Setyanto, A. E. 2005. Memperkenalkan Kembali Metode eksperimen dalam Kajian Komunikasi. Jurnal Ilmu Komunikasi., 3(1):37-48.
Shalaby, AME, Ashraf. AR dan Yassir. A.E.K. 2007. Sex Reversal of Nile Tilapia Fry Using Different Doses of $17 \alpha$-Metyltestosteron at Different Dietary Protein Levels. Central Laboratory for Aquaculture Research, Abbassa, Abo-Hammad, Sharkia Governorate, Egypt. 55pp.

Sibarani, Dian Afdelima, Titik Susilowati, Tristiana Yuniarti. 2015. Pengaruh Kepadatan Berbeda Menggunakan $r G H$ pada Pakan terhadap Pertumbuhan dan Kelangsungan Hidup Ikan Nila (Oreochromis niloticus) Journal of Aquaculture Management and Technology Volume 4, Nomor 3, Tahun 2015, Halaman 84-90

Simanjuntak, M. 2009. Hubungan Faktor Lingkungan Kimia, Fisika Terhadap Distribusi Plankton Di Perairan Belitung Timur, Bangka Belitung. Jurnal Perikanan. Vol. 9 (1). Hlm. 31-45.

Taylor, Robert. E And Thomas G. Field. 2004. Scientific Farm Animal Production : An Introduction To Animal Science (Eighth Edition). Pearson Prentice Hall. New Jersey..764 P.

SNI 6141-2009. Produksi Benih Ikan Nila Hitam (Oreochromis niloticus Bleeker) Kelas Benih Sebar. Badan Standarisasi Nasional (BSN). Jakarta.

Zooneveld, N. E., A. Huisman., dan J. H. Boon. 1991. Prinsip-prinsip Budidaya Ikan. PT. Gramedia Pustaka Utama. hlm.318. 